\title{
Music Notation Software as a Visual-aural Model in Self- regulated Practice
}

\section{Violetta Ayderova, Wong Huey Yi @ Colleen Wong, Christine Augustine}

To Link this Article: http://dx.doi.org/10.6007/IJARBSS/v11-i12/11268 DOI:10.6007/IJARBSS/v11-i12/11268

Received: 09 October 2021, Revised: 11 November 2021, Accepted: 25 November 2021

Published Online: 22 December 2021

In-Text Citation: (Ayderova et al., 2021)

To Cite this Article: Ayderova, V., Wong, W. H. Y. @ C., \& Augustine, C. (2021). Music Notation Software as a Visual-aural Model in Self-regulated Practice. International Journal of Academic Research in Business and Social Sciences, 11(12), 344-360.

\section{Copyright: (c) 2021 The Author(s)}

Published by Human Resource Management Academic Research Society (www.hrmars.com) This article is published under the Creative Commons Attribution (CC BY 4.0) license. Anyone may reproduce, distribute, translate and create derivative works of this article (for both commercial and non0-commercial purposes), subject to full attribution to the original publication and authors. The full terms of this license may be seen at: http://creativecommons.org/licences/by/4.0/legalcode

Vol. 11, No. 12, 2021, Pg. 344 - 360

Full Terms \& Conditions of access and use can be found at http://hrmars.com/index.php/pages/detail/publication-ethics 


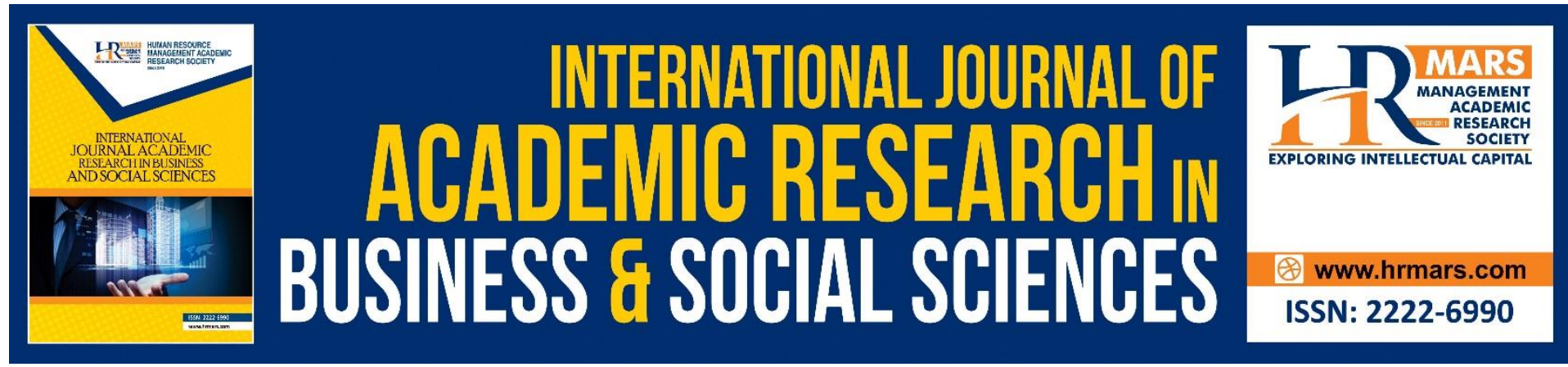

\title{
Music Notation Software as a Visual-aural Model in Self-regulated Practice
}

\section{Violetta Ayderova, Wong Huey Yi @ Colleen Wong, Christine Augustine}

Universiti Pendidikan Sultan Idris, 35900 Tanjong Malim, Perak, Malaysia

Email: violetta@fmsp.upsi.edu.my

\begin{abstract}
Managing self-regulated strategies while learning a piece of music is a complex task for undergraduate music students - at various levels of experience playing instrumentsstudying applied music courses. This study investigates music notation software as a visualaural model to students' effective practice. Twenty students of stringed instruments at levels I, II, III, and IV of an applied music course offered by the music faculty of a Malaysian university participated in this quantitative study, which was implemented using a self-report questionnaire. The results reveal that regardless of the student's level in the applied music course, music notation software has a positive effect on students' self-regulation practice strategies aimed at improving their shortcomings (including matching intonations and using proper phrasings, rhythmic patterns, and tempo speeds). This study assessed one semester of study at the university. Future research examining the potential benefits of using music notation software in self-regulated practice of stringed instruments and other music instruments (including voice) should have students employ a self-reported diary to keep track of daily achievements and goals.
\end{abstract}

Keywords: Visual-aural Model, Self-Regulated Learning, Music Notation Software

\section{Introduction}

This paper reports the results from research undertaken to explore the self-regulated learning process of students of stringed instruments in combination with music notation software, with the intention to optimise the practice aspects in preparation for their end-of- semester assessment. The purpose of the research was to determine whether the music notation software reinforced the students' self-regulated strategies and practice experience over the semester. This research sought to demonstrate positive achievements in students' outcomes from self-learning strategies according to their applied music course level.

The COVID-19 lockdown in 2020 impacted the education process by moving educators and students towards the online mode (Kirby, 2020). During this challenging time, music instrument teachers needed to reconsider their teaching approaches by focusing on improvement in the students' self-regulated practice strategies and helping them find tools to facilitate their self-practice. 
Practice quality achievements in learning musical instruments directly depends on the time devoted to this endeavour and the understanding of the task (Aydner-Uygun \& Kılınçer, 2017; Philippe et al., 2020; Hallam et al., 2012; López-Íñiguezand \& McPherson, 2020; McPherson et al., 2017; Osborne et al., 2020; Woody, 2019). An interrelationship of emotions, cognition, and action behaviour is involved in self-regulated learning strategies (Antonini Philippe et al., 2020; López-Í̃̃iguezand \& McPherson, 2020; McPherson et al., 2017; Osborne et al., 2020). According to McPherson (2017), the students with abilities to manage their own learning strategies are 'considered as successful'. Incorporating self-direction and selfevaluation in conveying the content of learned music by visualising, observing, and listening leads to effective practice (Aydner-Uygun \& Kılınçer, 2017; Hallam et al., 2012; Ross, 2013; Woody, 2019). Self-regulation strategies improve efficiency, which is vital for individuals' development in music expertise (López-Íñiguezand \& McPherson, 2020; McPherson et al., 2017; Miksza, 2011; Varela et al., 2014), as shown in Zimmerman's framework model (Zimmerman, 2000, 2002, 2003).

To date, no other studies have explored the role of music notation software as a visualaural model in self-regulated practice. Moreover, there are no studies on the influence of music notation software on the effectiveness stringed instruments practice with students taking applied music courses in diploma and degree programs.

Some studies have been conducted on the various strategies to improve practice quality by the self-regulated method, which typically focused on the live or recorded components of the model (Hallam et al., 2012; Hewitt, 2001; Ross, 2013); however, little research on implementing music notation software as a visual-aural model has been done.

Hewitt (2001) observed that previous research has shown that aural models are effective in developing students' abilities to detect errors they made in notes, rhythms, dynamics, and tempos. Furthermore, he indicated that in practice situations, the recorded model is preferable in terms of accessibility and consistency. Hewitt (2001) examined the aural model's effects on practice and music performance with junior high school instrumentalists from the seventh to ninth grade. The study showed that students who used the aural recorded model increased their playing skills in rhythmic accuracy, technique, tempo, and interpretation (p. 318). However, research on the effects of using music notation software (Galera et al., 2013; Nart, 2016) as a source for developing self-regulated practice strategies towards improving practice skills has not been extensive.

The study conducted by Galera et al. (2013) was aimed at solving the problem of knowledge acquisition in students with varied musical backgrounds regarding their abilities to adapt more quickly to Western music notation by using music notation software that incorporated the aural and visual model. This study relied on previous studies of the efficacy of music notation software environment related to the sounds and symbols of music (see Buck,1991; Goodwin,1991; Platte,1981; Prasso, 1997; in Galera et al., 2013). Galera and colleagues concluded that using music notation software effectively simplifies the process of learning and adapting to musical scores.

Nart (2016) examined various music software for its potential use in education. He interpreted the obtained data and subdivided it into representing five types of software: tutorial, drill and practice, game, notation, sequencing, and recording. Nart suggested that the music notation software be implemented in Turkish music education as it could facilitate educators' and undergraduate students' practice process in several aspects, such as visualising and listening over the inserted melody and harmonised accompaniment part, learning the rhythmic features, and using the integrated metronome to play in time. In 
addition, the software allows all parts of the digital written score to be modified and corrected according to the students' needs. Nart (2016) suggested that using the music notation software could aid self-learning in students with different learning styles and speeds and help them improve their sense of rhythm and tempo, along with their ability to listen attentively and play along with a non-live accompaniment. Thus, music notation software can effectively contribute to the aural and visual self-learning process of students and the teaching resources of educators.

A study on practice strategies by Hallam et al. (2012) identified seven important factors, including listening to the recordings, which had a significant relationship to the systematic practice and level of expertise (2019, p. 746). The researchers pointed out that listening to recordings assists learners in developing expertise, especially at the beginner level of playing. Moreover, playing recordings on mobile phones is easy and accessible in both aural and visual modes (2012, p. 670). The strategy of listening to recordings is related to playing by ear, which has been extensively explored in studies showing that consistently listening to one's performance creates the imagination of 'what the music should sound like' (Woody, 2019). Woody's study (2019) with 28 undergraduate wind instrument students explored their ability to play by ear by listening to melodies played in a MIDI (Musical Instruments Digital Interface) (piano sound) produced on the computer. The students were required to memorise the melodies by singing them first, correctly reproducing them by voice, and then producing the sounds with their wind instruments. The students were offered two conditions for playing the melody: with no musically notated score and with the score of the harmony progression of a particular melody. The results revealed that playing by ear depends on students' experience of practicing in such conditions, which determines the number of attempts needed to attain the required accuracy in the melody. In addition, it was found that students with experience reading chord progressions prefer to see them during their performance a memorised melody. This study demonstrates the relationship between the aural and visual models of practice strategy. The strategies applied to the effective practice of learning a piece include reading, listening to and imitating the melody patterns multiple times, and matching the pitch of notes until it becomes firmly internalised, all of which impact the quality of a performance (Hallam et al., 2012, 2013, 2019, 2021; Ross, 2013; Williamon \& Valentine 2000).This can be similarly conceptualised as a self-regulation model that includes organization, management, and motivation, which serves to control and develop certain aspects of the learning process (Hallam et al., 2021; McPherson \& Zimmerman, 2011).

Based on the above studies, the hypothesis of the present study is that by using music notation software as a visual-aural model in the process of learning a piece of music, students will improve their skills in analysing, imitation, intonation, rhythm, and pace. Additionally, it can be predicted that a student's mastery and confidence will increase in line with the amount of persistent practice with music notation software regardless of their level in their applied music course. The practice with the music notation software should supplement selfregulated practice strategies in terms of the organisation of the practice and the conscious concentration on different aspects of music, through the three-phase model described as follows.

The forethought phase involves students' self-direction in analysing a piece of music they are preparing for final assessment through visualising, listening, and singing along with the score in the music notation software. As a follow-up, students are expected to plan their practice strategy according to their identified difficulties and focus on these while developing their competence in learning music. Moreover, using the music notation software with an 
integrated metronome and the assembled accompaniment part for melody during practice contributes to students' satisfaction with their learning outcomes. McPherson and Zimmerman indicated that self-efficacy as self-belief means that 'students who believe in their own capacity are more likely to persist despite obstacles, encouragement, and confirmatory feedback' (2011, p. 140). The performance or task-oriented phase (McPherson \& Zimmerman, 2011, p. 142) involves students' focus on the proper playing of the intonation, referring to the melody pitches on the music notation software, and controlling the speed and accompaniment by using the metronome. This is done while interpreting the content of the learned music in terms of its phrasings and striving to convey its emotional meaning. The self-reflection phase relies on observing and examining one's own recorded video, determining what has been achieved and identifying and refining the weaker parts. This involves formulating strategies to strengthen one's practice to ensure quality of playing in preparation for the upcoming performance.

The present study is limited to a sample of stringed instrument students; therefore, the effectiveness of their achievements in practice was explored according to their levels in the applied music course (I, II, III, IV) in which they were studying.

The study set out to address the following questions:

- What type of music notation software is preferable for students to use?

- Does the amount of experience in using music notation software and the weekly amount of practice impact the student's expertise?

- Do the functions of music notation software facilitate students' practice strategies in learning a piece of music?

- Do the self-regulated practice abilities and concentration develop according to the course level of a student's study?

- Does the adoption of music notation software contribute to the student's quality of expertise?

\section{Method}

Design

This study focused on investigating students' experience of using music notation software in conjunction with self-regulated practice strategies in an applied music course. The quantitative study was conducted over a period of one semester, and the data were collected through a self-reported questionnaire.

\section{Materials}

The questionnaire implemented in this study on practice strategies was borrowed and slightly modified from 'The development of practicing strategies in young people' (Hallam et al., 2012). The 27 statement items were slightly modified, and 15 statements were added to obtain comprehensive data related to the use of the music notation software.

\section{Participants}

The scope of the ongoing study was limited to Malaysian students in the state of Perak, who were studying in the Faculty of Music and Performing Arts of Universiti Pendidikan Sultan Idris during the 2020-2021 academic years. The participants of this study were students $(n=20)$ of the diploma (25\%) and undergraduate music degree programmes (75\%), consisting of 15 females (75\%) and five males (25\%) aged between 19 and 23 years ( $M=21,45 ; S D=1.05$ ). The 20 music students were in their first to fourth course of their applied music programme and were learning stringed instruments (violin $=15 \%$; viola $=85 \%$ ). The total duration of the 
participants' preparation for the final assessment was 14 weeks. The Pearson's correlation between applied course level and age was $r=.317, p=.174$.

\section{Instrumentation}

The present study adopted a self-report questionnaire as a means of collecting data from a small sample of students $(n=20)$ subdivided into four groups according to their course level: Level-I $(n=5)$, Level-II $(n=3)$, Level-III $(n=5)$, Level-IV $(n=7)$. The first part of the questionnaire consists of demographic information (musical instrument, course level, university programme, and age); see Table 1 . The descriptive statistics and analysis of variance (one-way ANOVA) were used to analyse the data, with expertise in using the music notation software as the independent variable and practice strategies with music notation software as the dependent variables (Hallam et al., 2012). JASP v. 0.14.1 (Computer software) was used for the statistical data analysis jointly with a spreadsheet to obtain effect size indices adequate to the design.

Table 1. Participants' Instruments, Levels, and Programmes

\begin{tabular}{|c|c|c|c|c|c|c|}
\hline Instrument & $\begin{array}{l}\text { Applied } \\
\text { Music } \\
\text { Course }\end{array}$ & $\begin{array}{l}\text { Study } \\
\text { Program }\end{array}$ & $\begin{array}{l}\text { Number } \\
\text { of } \\
\text { Students }\end{array}$ & Percentage & $\begin{array}{l}\text { Mean } \\
\text { Age }\end{array}$ & $\begin{array}{l}\text { Standard } \\
\text { Deviation }\end{array}$ \\
\hline Viola & Level I & Degree & 5 & $25 \%$ & 21.2 & 0.5 \\
\hline Viola & Level II & $\begin{array}{l}\text { Degree (1) } \\
\text { Diploma } \\
\text { (2) }\end{array}$ & 3 & $15 \%$ & 20.0 & 1.0 \\
\hline Viola & Level III & Degree & 5 & $25 \%$ & 22.4 & 0.5 \\
\hline $\begin{array}{l}\text { Viola (5) } \\
\text { Violin (3) }\end{array}$ & Level IV & $\begin{array}{l}\text { Degree (5) } \\
\text { Diploma } \\
\text { (2) }\end{array}$ & 7 & $35 \%$ & 21.6 & 0.9 \\
\hline
\end{tabular}

The remaining questionnaire sections collected information about students' experiences and time durations using the music notation software, including in conjunction with self-regulated learning. The students were asked to indicate their number of practice days in a week and the duration of their practice time daily using the music notation software. In addition, they were required to indicate their strategies in learning a piece of music using the notation software, as well as rate their level of confidence and mastery in preparation for performing the piece. Overall, the questionnaire is subdivided according to the research purposes and consists of 42 items. The internal consistencies of the entire set of questions were measured by Cronbach's alpha empirical test and ranged from 0.50 to 0.89 , which indicates overall an acceptable reliability correlation between the questions.

Procedure

The students of stringed instruments were verbally invited to participate in the study on a voluntary basis and were assured that the data would remain confidential. The students indicated their consent by completing self-report questionnaires designed on Google forms and distributed to the participants by email. The respondents were requested to choose the most appropriate statements on a five-point Likert (1932) scale (surely not-1 to surely yes-5) to indicate their experience in utilising music notation software in self-regulated practice on an assigned piece of music during one semester. In this regard, all the answers in the questionnaires were considered as true. 
Before the study starts, students were instructed and monitored by the teachers during online classes in the use of practice strategies with the digital scores on the music notation software. According to their course level, students prepared pieces of music according to the level requirements of the semester. One of the strategies is to control the quality of the intonation by alternating between listening to the entire piece and singing to match the melody pitches, remembering the melody accurately before proceeding, and then placing their fingers on the instrument and imitating the melody as closely as possible (Woody, 2019). Another strategy is to match the pulse of the pace with beat counting, and to realise the proper rhythmic patterns, they were instructed to follow the integrated metronome in the music software. In addition, the students were suggested to type in (if not included) the piano accompaniment part to obtain the entire scope of the composition and elaborate their interpretation of the piece. Moreover, the teacher created a video demonstrating how to use the tools in the music notation software to develop their abilities in adjusting the tempo and their confidence playing along with the accompaniment part.

\section{Results}

\section{What type of music notation software is preferable for students to use?}

The respondents were asked to indicate on a self-report questionnaire the type of music notation software they prefer to use. This part of the data was collected in Google forms, in which the participants indicated their preference for Sibelius (88.9\%), MuseScore $(5.55 \%)$, and Finale (5.55\%) music notation software.

Does the amount of experience in using music notation software and the weekly amount of practice impact the student's expertise?

The data obtained in the participants' self-reported questionnaires were analysed. Descriptive statistics with mean intervals (1-Strongly disagree $=1.00-1.49 ; 2$-Disagree $=1.50$ 2.49; 3-Undecided $=2.50-3.49 ; 4$-Agree $=3.50-4.49 ; 5$-Strongly Agree $=4.50-5.00)$. The analysis of variance test (Williamon et al., 2021) with the main effect of the level of the studied course in Levene's $F$ test assumptions of error variances assumption was conducted for the dependent variables of each statement item in the questionnaire to explore whether there were linear trends and an overall average in Fisher's test for independent and dependent variables. In addition, the partial eta squared index was calculated to obtain the effect size according to the criteria proposed by Cohen (1988) for small (.01), medium (.06), and large (.14) effect sizes.

According to Table 2, the analysis of the five statement items about the students' experience in terms of the duration of using the music notation software revealed that the highest duration from 6 months to 1 year was displayed by group Level IV ( $M=5.0 ; S D=0.0$ ), which indicates a significant effect between groups in the homogeneity of variances test (Levene's), $\boldsymbol{F}(3,16)=10,5 ; p<.001$. Likewise, the significant effect $\boldsymbol{F}(3,16)=10,6 ; p<.001$ appeared in the duration 1 year to 2 years of group Level III $(M=5.0 ; S D=0.0)$. Less experience in the use of music notation software over all the duration statements, with satisfaction agreement, was displayed by group Level II $(M=3.7 ; S D=1.2)$ in the duration from 6 months to 1 year. Likewise, the duration of over 2 years of use was indicated by group Level III ( $M=$ 4.0; SD =1.2). The overall average in the Fisher's test indicated a significant effect, and a large effect size was reached on the level of expertise in terms of the number of months using the music notation software $F(3,16)=3.58, p=0.037, \eta 2 p=.40(p<0.05)$. 
Table 2. Comparisons of Students' Experience in Using the Music Notation Software

\begin{tabular}{|c|c|c|c|c|c|c|}
\hline $\begin{array}{l}\text { Applied Music Course } \\
\text { Grade Level }\end{array}$ & Level-I & Level-II & Level-III & Level-IV & Total & $\begin{array}{l}\text { Levene's } \\
\text { p-value }\end{array}$ \\
\hline Number of students & 5 & 3 & 5 & 7 & 20 & \\
\hline 1 week to 1 month & 1.40 & 1.33 & 1.40 & 2.00 & 1.5 & 0.937 \\
\hline 1 month to 6 months & 4.0 & 3.3 & 2.6 & 3.1 & 3.2 & 0.417 \\
\hline 6 months to 1 year & 3.8 & 3.7 & 4.6 & 5.0 & 1.9 & $<.001$ \\
\hline 1 year to 2 years & 3.6 & 2.3 & 5.0 & 4.1 & 3.7 & $<.001$ \\
\hline Over 2 years & 2.6 & 2.0 & 4.0 & 3.7 & 3.1 & 0.097 \\
\hline
\end{tabular}

Note: For each item, the students scored their activities on a Likert scale of 1 to 5 (1= surely not, 2 = partly not,

$3=$ undecided, $4=$ partly yes, $5=$ surely yes)

In Table 3, the number of days the students reported practicing utilising the music notation software, revealed in mean values, shows that significant use was demonstrated by Level-III in two days a week ( $M=4.6$; $S D=0.6)$, while the students from Level-II used the software only one day a week ( $\mathrm{M}=4.3 ; \mathrm{SD}=0.6)$. In addition, three days a week practice was indicated by students from Level-I, with a mean of 4.0 and a slightly different standard deviation. There was no significant effect between the weekly practice days according to the homogeneity of variances test (Levene's). Overall weekly days practice was not statistically significant with a large level effect size, $F(3,16)=1,41, p=0.278, \eta 2 p=.21(p<0.05)$, indicating that experience in using the music notation software does not have an effect on the number of days of practice in a week.

Table 3. Practice on Instrument Using Notation Software (Weekly)

\begin{tabular}{lllllll}
\hline $\begin{array}{l}\text { Applied Music Course } \\
\text { Grade Level }\end{array}$ & Level-I & Level-II & $\begin{array}{l}\text { Level- } \\
\text { III }\end{array}$ & Level-IV & Total & $\begin{array}{l}\text { Levene's } \\
\text { p-value }\end{array}$ \\
\hline Number of students & 5 & 3 & 5 & 7 & 20 & \\
\hline 1 day a week & 3.4 & 4.3 & 4.0 & 3.7 & 3.85 & 0.074 \\
2 days a week & 3.8 & 4.0 & 4.6 & 4.0 & 4.1 & 0.652 \\
3 days a week & 4.0 & 3.3 & 4.0 & 4.0 & 3.8 & 0.924 \\
Every day & 2.4 & 2.7 & 2.8 & 3.4 & 2.8 & 0.353 \\
No one day in a week & 1.6 & 2.7 & 2.2 & 2.1 & 2.2 & 0.710 \\
\hline
\end{tabular}

\section{Do the functions of music notation software facilitate students' practice strategies in learning a piece of music?}

In a statement of abilities to manipulate the music notation software during the practice session, the highest mean was indicated by the students in Level-III. These abilities include to adjust speed of music $(M=5.0 ; S D=0.0)$, adjust volume or reduce sound of accompaniment part $(\mathrm{M}=4.80 ; \mathrm{SD}=0.5)$, can type the notes in different clefs $(\mathrm{M}=4.0 ; \mathrm{SD}=0.7)$, and can add the dynamic nuances inside the score $(M=4.40 ; S D=0.6)$. The less- developed abilities, as indicated by the statement can type the notes in different clefs $(\mathrm{M}=2.33$; $S D=0.7)$ were displayed by Level-II. The significant effect, according to the homogeneity of variances test (Levene's), was revealed by the statement adjust volume or reduce sound of accompaniment part, $\boldsymbol{F}(3,16)=29.18 ;<.001$ (see Table 4). The overall average results of the four statements of abilities in manipulating the music notation software did not reveal a significant effect, $F$ 
$(3,16)=2,44, p=0.102, \eta 2 p=.31(p<0.05)$, with the large effect size indicating that students from all four levels were able to practice effectively with the software.

Table 4. Ability to Manipulate the Music Notation Software

\begin{tabular}{|c|c|c|c|c|c|c|}
\hline Applied Music Course Grade Level & $\begin{array}{l}\text { Level- } \\
\text { I }\end{array}$ & $\begin{array}{l}\text { Level- } \\
\text { II }\end{array}$ & $\begin{array}{l}\text { Level- } \\
\text { III }\end{array}$ & $\begin{array}{l}\text { Level- } \\
\text { IV }\end{array}$ & Total & $\begin{array}{l}\text { Levene's } \\
p \text {-value }\end{array}$ \\
\hline Number of students & 5 & 3 & 5 & 7 & 20 & \\
\hline Adjust speed (tempo) & 4.6 & 4.7 & 5.0 & 4.4 & 4.7 & $<.001$ \\
\hline $\begin{array}{l}\text { Adjust volume or reduce sound of } \\
\text { accompaniment part }\end{array}$ & 4.2 & 4.0 & 4.8 & 3.8 & 4.2 & 0.147 \\
\hline $\begin{array}{l}\text { Able to type the notes in different } \\
\text { clefs }\end{array}$ & 3.2 & 2.3 & 4.0 & 2.9 & 3.1 & 0.767 \\
\hline $\begin{array}{l}\text { Able to add the dynamic nuances } \\
\text { inside the score }\end{array}$ & 3.2 & 3.0 & 4.4 & 3.9 & 3.6 & 0.829 \\
\hline
\end{tabular}

In Table 5, it can be seen that students mostly focused on listening to a piece of music on the notation software in order to understand sections and phrases inside the piece, which mostly was indicated by students from Level-I, and in order to understand the expression of music and technique requirements, which was indicated the most by Level-I and Level-III students and less by Level-IV and Level-II. None of the four groups exhibited a medium interest in the statement understand genre and style of the piece. The Level-IV students were mostly interested in listening to the piece of music in order to understand sections and phrasings. Overall, there was no significant difference $F(3,16)=0,449 p=0.721, \eta 2 p=.08(p<0.05)$ in the medium effect size in terms of understanding the musical features by listening to the music notation software.

Table 5. Strategy of Listening to Piece on the Music Notation Software

\begin{tabular}{|c|c|c|c|c|c|c|}
\hline $\begin{array}{l}\text { Applied Music Course Grade } \\
\text { Level }\end{array}$ & Level-I & Level-II & $\begin{array}{l}\text { Level- } \\
\text { III }\end{array}$ & Level-IV & Total & $\begin{array}{l}\text { Levene's } \\
p \text {-value }\end{array}$ \\
\hline Number of students & 5 & 3 & 5 & 7 & 20 & \\
\hline $\begin{array}{l}\text { To understand sections and } \\
\text { phrases inside the piece }\end{array}$ & 4.2 & 3.3 & 3.8 & 4.0 & 3.8 & 0.093 \\
\hline $\begin{array}{l}\text { To understand genre and } \\
\text { style of the piece }\end{array}$ & 3.6 & 3.3 & 3.8 & 3.3 & 3.5 & 0.555 \\
\hline $\begin{array}{l}\text { To understand the expression } \\
\text { of music and technique } \\
\text { requirements }\end{array}$ & 4.2 & 4.0 & 4.6 & 3.7 & 4.1 & 0.525 \\
\hline
\end{tabular}

Table 6 shows that the students mostly focused on trying to adjust and produce the feeling of the piece of music by referring to the notation software, which was mostly indicated by the students from Level-III. Overall, there was no significant difference $F(3,16)=0,792, p=0.516$, $\eta 2 \mathrm{p}=.12$

$(p<0.05)$ in the medium effect size according to understanding the musical features and producing the content of the piece. 
Table 6. Ability to Understand and Produce the Content of the Piece

\begin{tabular}{|c|c|c|c|c|c|c|}
\hline $\begin{array}{l}\text { Applied Music Course Grade } \\
\text { Level }\end{array}$ & Level-I & Level-II & $\begin{array}{l}\text { Level- } \\
\text { III }\end{array}$ & Level-IV & Total & $\begin{array}{l}\text { Levene's } \\
p \text {-value }\end{array}$ \\
\hline Number of students & 5 & 3 & 5 & 7 & 20 & \\
\hline $\begin{array}{l}\text { Try to catch and produce the } \\
\text { mood of the piece of music }\end{array}$ & 3.4 & 4.3 & 4.2 & 3.6 & 3.9 & 0.224 \\
\hline $\begin{array}{l}\text { Try to adjust and produce the } \\
\text { feeling of the piece of music }\end{array}$ & 3.8 & 4.3 & 4.2 & 3.7 & 4.0 & 0.432 \\
\hline $\begin{array}{l}\text { Try to imagine a story in the } \\
\text { piece and interpret it in the } \\
\text { playing }\end{array}$ & 3.2 & 3.0 & 3.6 & 3.6 & 3.35 & 0.005 \\
\hline
\end{tabular}

Do the self-regulated practice abilities and concentration develop according to the course level of a student's study?

In the self-report questionnaire, the students indicated their use of the music notation software by applying several integrated functions (see Table 7). According to the homogeneity of variances test (Levene's), there was a slightly significant effect, $F(3,16)=8,397, p=0.001$ $(p<0.05)$ on the statement listen and imitate the rhythmic patterns, as demonstrated by the highest average indication over the entire four groups. Overall, the ANOVA (Fisher's) results reveal that there was no significant difference $F(3,16)=0,125, p=0.944, \eta 2 p=.02(p<0.05)$ in the small effect size between the four groups regarding practicing the instrument along with the software in terms of the technical and musical aspects.

Table 7. Focus and Work on Technical Aspects

\begin{tabular}{lllllll}
\hline $\begin{array}{l}\text { Applied Music Course Grade } \\
\text { Level }\end{array}$ & $\begin{array}{l}\text { Level-I } \\
\text { Number of students }\end{array}$ & $\begin{array}{l}\text { Level- } \\
\text { II }\end{array}$ & $\begin{array}{l}\text { Level- } \\
\text { III }\end{array}$ & $\begin{array}{l}\text { Level- } \\
\text { IV }\end{array}$ & $\begin{array}{l}\text { Tota } \\
\text { I }\end{array}$ & $\begin{array}{l}\text { Levene's } \\
\text {-value }\end{array}$ \\
\hline $\begin{array}{l}\text { Practice on tempo by using } \\
\text { integrated metronome }\end{array}$ & 4.0 & 4.7 & 4.6 & 4.7 & 4.5 & 0.120 \\
$\begin{array}{l}\text { Listen and imitate the rhythmic } \\
\text { patterns }\end{array}$ & 4.6 & 5.0 & 4.8 & 4.4 & 4.7 & 0.001 \\
$\begin{array}{l}\text { Type the fingerings and } \\
\text { practice them by visual and } \\
\text { play }\end{array}$ & 3.2 & 2.3 & 3.4 & 2.7 & 2.9 & 0.206 \\
$\begin{array}{l}\text { Listen to and imitate the } \\
\text { melody pitches in control }\end{array}$ & 4.4 & 4.3 & 3.8 & 3.7 & 4.1 & 0.793 \\
$\begin{array}{l}\text { intonation } \\
\text { Listen to and imitate the } \\
\text { difficult technical excerpts by }\end{array}$ & 4.6 & 4.0 & 4.4 & 4.6 & 4.4 & 0.777 \\
repeating them several times & & & & & & \\
\hline
\end{tabular}

As shown in Table 8, on average, the responses to the self-regulated practice statements regarding the process of preparing a piece of music for an upcoming assessment show that the students exhibited the most confidence playing along with the accompaniment part typed inside the music notation software. Overall, the ANOVA (Fisher's) results reveal that there was no significant effect $F(3,16)=1,84, p=0.180, \eta 2 p=.25(p<0.05)$ in the large effect size 
between the four groups in practicing their instrument along with the software in terms of self-regulated confidence in preparing a piece of music.

Table 8. Confidence in Performing Piece

\begin{tabular}{|c|c|c|c|c|c|c|}
\hline $\begin{array}{l}\text { Applied Music Course Grade } \\
\text { Level }\end{array}$ & Level-I & Level-II & Level-III & Level-IV & Total & $\begin{array}{l}\text { Levene's } \\
p \text {-value }\end{array}$ \\
\hline Number of students & 5 & 3 & 5 & 7 & 20 & \\
\hline Able to play the entire piece & 4.0 & 2.7 & 4.4 & 3.6 & 3.7 & 0.396 \\
\hline $\begin{array}{l}\text { Able to play the entire piece } \\
\text { with accompaniment part }\end{array}$ & 4.0 & 3.0 & 4.6 & 4.6 & 4.1 & 0.777 \\
\hline $\begin{array}{l}\text { Able to play the entire piece } \\
\text { with good intonation }\end{array}$ & 3.8 & 2.7 & 2.8 & 3.1 & 3.1 & 0.826 \\
\hline $\begin{array}{l}\text { Able to play the entire piece } \\
\text { and express phrasings }\end{array}$ & 3.4 & 2.3 & 3.8 & 3.6 & 3.3 & 0.395 \\
\hline $\begin{array}{l}\text { Able to play and express the } \\
\text { mood of the entire piece }\end{array}$ & 3.4 & 3.3 & 3.8 & 3.6 & 3.5 & 0.296 \\
\hline
\end{tabular}

Does the adoption of music notation software contribute to the student's quality of expertise?

The self-evaluation of one's own video recording was considered from the point of view of overall readiness to perform in the assessment and what needs be improved. According to Table 9, the highest agreement was with body posture, indicating that the students evaluated themselves meticulously. Overall, the ANOVA (Fisher's) results reveal that there was no significant effect $F(3,16)=1,66, p=0.215, \eta 2 p=.23(p<0.05)$ in the large effect size between the four groups in relation to self-evaluation.

Table 9. Evaluation of One's Own Video Recording

\begin{tabular}{|c|c|c|c|c|c|c|}
\hline $\begin{array}{l}\text { Applied Music Course } \\
\text { Grade Level }\end{array}$ & Level-I & Level-II & Level-III & Level-IV & Total. & $\begin{array}{l}\text { (Levene's } \\
p \text {-value }\end{array}$ \\
\hline Number of students & 5 & 3 & 5 & 7 & 20 & \\
\hline I like my facial expression & 3.6 & 3.0 & 3.2 & 3.9 & 3.4 & 0.640 \\
\hline I like my body posture & 3.8 & 3.0 & 4.0 & 4.0 & 3.7 & 0.979 \\
\hline $\begin{array}{l}\text { I make technical errors } \\
\text { often }\end{array}$ & 2.8 & 3.3 & 2.6 & 2.9 & 2.9 & 0.776 \\
\hline $\begin{array}{l}\text { I performed a good } \\
\text { intonation of pitch on } \\
\text { each note }\end{array}$ & 3.4 & 2.0 & 2.4 & 3.0 & 2.7 & 0.002 \\
\hline $\begin{array}{l}\text { I was able to play all } \\
\text { dynamic expressions (loud } \\
\text { or soft) pointed to in the } \\
\text { piece }\end{array}$ & 3.2 & 2.0 & 2.4 & 2.3 & 2.5 & 0.037 \\
\hline
\end{tabular}

According to Table 10, students mostly focus on the aspect to of playing a piece of music without accidental mistakes and struggle to perform proper dynamic nuances. The 
homogeneity of variances test (Levene's) revealed that there was a slightly significant effect, $F(3,16)=4,266, p=0.022(p<0.05)$, on the statement of readiness to play a piece of music non-stop from beginning to end. Overall, the ANOVA (Fisher's) results reveal that there was no significant effect, $F(3,16)=1,65, p=0.217, \eta 2 p=.23(p<0.05)$, with the large effect size between the four groups in relation to their readiness to perform a music piece in their upcoming assessment.

Table 10. Readiness of Piece in Different Aspects

\begin{tabular}{|c|c|c|c|c|c|c|}
\hline $\begin{array}{l}\text { Applied Music Course Grade } \\
\text { Level }\end{array}$ & Level-I & $\begin{array}{l}\text { Level- } \\
\text { II }\end{array}$ & $\begin{array}{l}\text { Level- } \\
\text { III }\end{array}$ & $\begin{array}{l}\text { Level- } \\
\text { IV }\end{array}$ & Total & $\begin{array}{l}\text { Levene's } \\
p \text {-value }\end{array}$ \\
\hline Number of students & 5 & 3 & 5 & 7 & 20 & \\
\hline $\begin{array}{l}\text { I can play non-stop until the } \\
\text { end of the piece }\end{array}$ & 3.6 & 2.0 & 3.6 & 3.6 & 3.2 & 0.022 \\
\hline $\begin{array}{l}\text { I focus on playing without } \\
\text { accidental mistakes }\end{array}$ & 4.8 & 4.3 & 4.4 & 4.6 & 4.5 & 0.353 \\
\hline $\begin{array}{l}\text { I make sure my intonation is } \\
\text { clear to bring to the } \\
\text { performance/exam }\end{array}$ & 4.4 & 4.0 & 4.2 & 4.0 & 4.2 & 0.811 \\
\hline $\begin{array}{l}\text { I express the rhythmic } \\
\text { sections or patterns properly }\end{array}$ & 4.4 & 3.3 & 3.6 & 4.0 & 3.8 & 0.050 \\
\hline $\begin{array}{l}\text { I have no mistakes in counting } \\
\text { beats }\end{array}$ & 4.4 & 3.0 & 3.8 & 3.9 & 3.8 & 0.339 \\
\hline $\begin{array}{l}\text { I have no mistakes in dynamic } \\
\text { nuances }\end{array}$ & 3.8 & 2.7 & 2.8 & 3.3 & 3.2 & 0.557 \\
\hline $\begin{array}{l}\text { I have no mistakes in } \\
\text { expression of phrases }\end{array}$ & 4.4 & 3.3 & 3.8 & 4.3 & 4.0 & 0.793 \\
\hline
\end{tabular}

Table 11 presents an overall descriptive analysis of the self-regulated development of transferable skills. Among all the statements, the self-regulated strategies on focus and work on technical aspects of the piece of music was rated the highest $(M=4.11, S D=0.49)$, followed by ability to manipulate the music notation software $(M=3.92, S D=0.68)$ and readiness of piece in different aspects $(M=3.86, S D=0.68)$. The frequency of using notation software (weekly) was rated the lowest $(M=3.00, S D=0.49)$, followed by experience in use of music notation software $(\mathrm{M}=3.19, \mathrm{SD}=0.72)$ and evaluation of one's own video recording $(\mathrm{M}=3.35, \mathrm{SD}=0.58)$. 
Table 11. Overall Transferable Skills

\begin{tabular}{|c|c|c|c|}
\hline Transferable skill item & Mean & SD & Cronbach's $\alpha$ \\
\hline $\begin{array}{l}\text { Experience in use of music notation software } \\
\text { Questions 1-5 }\end{array}$ & 3.19 & 0.72 & 0.69 \\
\hline $\begin{array}{l}\text { Frequency of using notation software (weekly) } \\
6-10\end{array}$ & 3.00 & 0.49 & 0.52 \\
\hline $\begin{array}{l}\text { Ability to manipulate the music notation software } \\
\text { Questions } 11-14\end{array}$ & 3.92 & 0.68 & 0.86 \\
\hline $\begin{array}{l}\text { Strategy of listening to piece on music notation } \\
\text { software } \\
\text { Questions 15-17 }\end{array}$ & 3.83 & 0.75 & 0.84 \\
\hline $\begin{array}{l}\text { Ability to understand and produce the content of } \\
\text { the piece } \\
\text { Questions } 18-20\end{array}$ & 3.72 & 0.59 & 0.68 \\
\hline $\begin{array}{l}\text { Focus and work on technical aspects } \\
\text { Questions } 21-25\end{array}$ & 4.11 & 0.49 & 0.62 \\
\hline $\begin{array}{l}\text { Confidence in performing piece } \\
\text { Questions 26-30 }\end{array}$ & 3.61 & 0.71 & 0.821 \\
\hline $\begin{array}{l}\text { Evaluation of one's own video recording } \\
\text { Questions 31-35 }\end{array}$ & 3.35 & 0.58 & 0.501 \\
\hline $\begin{array}{l}\text { Readiness of piece in different aspects } \\
\text { Questions } 36-42\end{array}$ & 3.86 & 0.68 & 0.892 \\
\hline
\end{tabular}

\section{Discussion}

The current study aimed to explore the effects of implementing music notation software in students' self-regulated practice strategies in learning instruments in applied music courses at university diploma and degree programmes in Malaysia. It was predicted that by learning a piece of music using music notation software as a visual-aural model, students would enhance different aspects of their technical and musicianship abilities during one semester regardless of the level of the applied music course. The findings of the study show that music notation software has a positive effect on students' self-regulation practice abilities in conjunction with learning strategies, such us self-instruction in intonation, sense of rhythm, and pace. Students with more expertise and from a higher course level indicated more detailed approaches, such as task strategy in their practice (consistent practice on awkward music excerpts, turning them into daily goal exercises with the music notation software) and spent more time in contrast to less experienced students (practiced an entire piece over and over to be able to play it to the end). However, all participants indicated that they did not practice their instrument every day due to other university assignments. This finding was consistent with a previous study that focused on learner's expertise and practice development (Hallam, 2012). Furthermore, the study revealed that students who had experience using music notation software tended to practice with it consistently and efficiently to correct their shortcomings, working on aspects such as matching intonation and developing proper phrasings, rhythmic patterns, and various tempo speeds. In contrast, the beginner students who had just started to play on a stringed instrument and use music notation software preferred first to analyse the content of a piece of music by listening, visualising, and then singing along to the entire piece or excerpts on a notation software player, although they did not tend to practice with an integrated metronome. Therefore, the 
music software player helps students to scan and analyse the music by sight and by ear in order to identify possible obstacles. Altogether, the students indicated that to establish an appropriate feel of the tempo, rhythmic features, and melody phrases of the entire music piece, they used the strategy of chanting and singing the melody (beginning to end, or by problem sections) to clarify and make corrections in their instrument playing sound. Competence in using music notation software would support students to develop selfdirection strategies in learning more complex pieces. Taken together, the results show that the students were able to independently master their practice process despite their experience level and chosen strategies.

These study results are in partial accordance with the results of studies that explored the effectiveness of using aural models on students' musical development abilities (Hewitt, 2001), including faster adaptation to Western music notation by utilising the music notation software as an aural-visual model (Galera et. al., 2013). The results corroborate that aural and visual models effectively support the practice process of learning a music piece in terms of rhythm, tempo, and interpretation. Moreover, this study found that using an integrated metronome and a typed accompaniment part in music notation software facilitated the students' practice in controlling the speed of a learned melody and feeling its harmonisation.

This study substantiates Nart's (2016) finding that music can be learned faster by utilising music notation software by providing visual and aural support to students in their development of self-regulated learning skills. Students can repeat the melody and rhythmic patterns as many times as needed, as well as use transcribed accompaniment and drill skills to play along in an ensemble. However, in order to progress in their practice using the notation software, students must first be instructed in how to use it and guided by a teacher who provides solutions and feedback around the obstacles they encounter.

Additionally, the results of this study partially align with those of previous studies focused on effective self-regulated learning practice strategies (three-phase model) that music students can apply when practicing or performing on their stringed instruments, following an aural or visual model in listening, analysing, imitating, reading the Western notation score, and matching the pitches of notes multiple times until they become firmly internalised (Hallam et al., 2012, 2013, 2019, 2021; Ross, 2013; Williamon \& Valentine, 2000).

\section{Conclusion}

This study demonstrates the effective use of music notation software by students, outside of their classes, to maximise the effectiveness of self-regulated practice by experimenting with software and implementing new practice strategies. Students demonstrated their ability to independently practice and develop their technical and musicianship skills by following the music notation software as a visual-aural model. The study fills the gap in the literature by investigating music notation software as a visual-aural model in the self-regulated practice of students of stringed instruments from different levels of an applied music course in diploma and degree programmes. The limitation of this study is its focus on a small sample of stringed instrument participants within one faculty of music at a Malaysian university. Several future research directions could be facilitated by these findings in terms of examining the potential benefits of self-regulated practice in using music notation software. These include (1) fostering the stringed instruments students to apply in their practice a self-reported diary to keep track of daily achievements and goals for the next-day practice session during semester time; (2) similar research with other music instruments/voice in using music notation software. 


\section{Implications for Education}

The evidence from this research suggests that music notation software as a visual-aural model is capable of supporting and facilitating the self-regulated practice strategies of students who have some experience manipulating the software. However, the beginning process of practicing with the music notation software should be guided and demonstrated by teachers to ensure students' effective practice. Teachers should regularly monitor students' practice with the music notation software and provide feedback that will help focus their attention on specific goals in improving technical and musicianship aspects. The teachers can demonstrate practice strategies, such as goal setting (identifying the mistakes and awkward passages and practicing them using different tempos and a metronome), and monitor their strategies (controlling intonation by listening to the melody, singing along, playing along at a slow tempo, and matching the pitch of every note in the melody) thereby encouraging students to develop their own self-regulated learning. In addition, teachers can provide their own videorecorded demo as a supplement to students' development and goal-setting regarding how the learned piece (pace, mood, expression) is meant to be performed.

\section{Acknowledgements}

We would like to express our special thanks to the Vice Chancellor of UPSI, Deputy Vice Chancellors of UPSI, and Research Management and Innovation Centre (RMIC) under Universiti Pendidikan Sultan Idris, Tanjung Malim, Malaysia for their strong support.

\section{References}

Philippe, A. R., Kosirnik, C., Vuichoud, N., Clark, T., Williamon, A., \& McPherson, G. E. (2020). Conservatory musicians' temporal organization and self-regulation processes in preparing for music exam. Frontiers in Psychology, 11. DOI: 10.3389/fpsyg.2020.00089

Aydiner-Uygun, M. (2020). Achievement goal orientations of students studying instrument education as predictors of their learning approaches, Music Education Research, 22 (2),130-144, DOI: 10.1080/14613808.2020.1713735

Aydiner-Uygun, M., \& Kılınçer, Ö. (2017). Strategies musicians use while practicing and learning instrumental music. In I. Koleva \& G. Duman (Eds.), Educational research and practice (pp. 400-409). Kliment Ohridski University Press.

Cohen, J. (1988). Statistical power analysis for the behavioural sciences ( $2^{\text {nd }}$ Ed.). Hillsdale, NJ: Lawrence Erlbaum Associates.

Galera, M. D., Tejada, J., \& Trigo, E. (2013). Music notation software as a means to facilitate the study of singing musical scores. Electronic Journal of Research in Educational Psychology, 11(1), 215-238. ISSNe: 1696-2095. DOI: https://doi.org/10.25115/ejrep.v11i29.1564

Hallam, S. (2013). What predicts level of expertise attained, quality of performance, and future musical aspirations in young instrumental players? Psychology of Music, 41(3), 267-291. https://doi.org/10.1177/0305735611425902

Hallam, S., Creech, A., Varvarigou, M., \& Papageorgi, I. (2019). Are there differences in practice depending on the instrument played? Psychology of Music, 48(6), 745765. https://doi.org/10.1177/0305735618816370

Hallam, S., Papageorgi, I., Varvarigou, M., \& Creech, A. (2021). Relationships between practice, motivation, and examination outcomes. Psychology of Music, 49(1), 320. https://doi.org/10.1177/0305735618816168 
Hallam, S., Rinta, T., Varvarigou, M., Creech, A., Papageorgi, I., Gomes, T., \& Lanipekun, J. (2012). The development of practising strategies in young people. Psychology of Music, 40(5), 652-680. https://doi.org/10.1177/0305735612443868

Hewitt, M. P. (2001). The effects of modeling, self-evaluation, and self-listening on junior high instrumentalists' music performance and practice attitude. Journal of Research in Music Education, 49(4), 307-322. https://doi.org/10.2307/3345614

JASP Team. (2020). JASP (Version 0.14.1) [Computer software].

Kirby, M. L. (2020). SEMPRE Autumn 2020 Conference: The role of music psychology research in a complex world. Music \& Science, 3(1), https://doi.org/10.1177/2059204320977126

López-Íñiguez, G., \& McPherson, G.E. (2020). Applying self-regulated learning and selfdetermination theory to optimize the performance of a concert cellist. Frontiers in Psychology. 11, 385. DOI: 10.3389/fpsyg.2020.00385

McPherson, G. E., Osborne, M. S., Evans P., \& Miksza, P. (2017). Applying self-regulated learning microanalysis to study musicians' practice. Psychology of Music. DOI: 10.1177/0305735617731614

McPherson, G. E., \& Zimmerman, B. J. (2011). Self-regulation of musical learning: A social cognitive perspective on developing performance skills. In R. Colwell \& P. Webster (Eds.), MENC handbook of research on music learning: Volume 2: Applications (pp.130175). Oxford Scholarship Online. DOI:10.1093/acprof:osobl/9780199754397.003.0004

Miksza, P. (2011). Relationships among achievement goal motivation, impulsivity, and the music practice of collegiate brass and woodwind players. Psychology of Music, 39(1), 50-67. doi: 10.1177/0305735610361996

Nart, S. (2016). Music software in the technology integrated music education. TOJET: The Turkish Online Journal of Educational Technology, 15(2), 78-84.

Osborne, M. S., McPherson, G. E., Miksza, P., \& Evans, P. (2020). Using a microanalysis intervention to examine shifts in musicians' self-regulated learning. Psychology of Music, 49(4), 972-988. DOI: 10.1177/0305735620915265

Ross, V. (2013). Music learning and performing: Applying written and oral strategies. Procedia - Social and Behavioral Sciences 90, 870-878. DOI: 10.1016/j.sbspro.2013.07.163

Varela, W., Abrami, P. C., \& Upitis, R. (2014). Self-regulation and music learning: A systematic review. Psychology of Music, 44(1), 55-74. DOI: 10.1177/0305735614554639

Woody, R. H. (2019). Musicians' use of harmonic cognitive strategies when playing by ear. Psychology of Music. 48(5), 674-692.DOI: 10.1177/0305735618816365

Williamon, A., Ginsborg, J., Perkins, R., \& Waddell, G. (2021). Inferential statistics: Differences. In Performing music research: Methods in music education, psychology, and performance science. Oxford University Press.

Williamon, A., \& Valentine, E. (2000). Quantity and quality of musical practice as predictors of performance quality. British Journal of Psychology, 91, 353376. https://doi.org/10.1348/000712600161871

Zimmerman, B. J. (2000). Self-efficacy: An essential motive to learn. Contemporary Educational Psychology, 25(1), 82-91. DOI: 10.1006/ceps.1999.1016

Zimmerman, B. J. (2002). Becoming a self-regulated learner: An overview. Theory Into Practice, 41(2), 64-70. DOI: 10.1207/s15430421tip4102_2 
Zimmerman, B. J., \& Campillo, M. (2003). Motivating self-regulated problem solvers. In J. E. Davidson \& R. J. Sternberg (Eds.) The psychology of problem solving (p. 239). Cambridge University Press. DOI: https://doi.org/10.1017/CBO9780511615771.009 